\title{
Penyengatan Meningeal Sisterna Basalis Meningitis TB pada Computed Tomography Scanning: Sebuah Ulasan Bergambar
}

\author{
Anastasia Tjan ${ }^{1 *}$, Made Widhi Asih², Elysanti Dwi Martadiani ${ }^{3}$ \\ Departemen Radiologi, Fakultas Kedokteran Universitas Udayana - RSUP Sanglah ${ }^{1}$ \\ Konsultan Neuroradiologi dan Head-Neck Radiolog, Fakultas Kedokteran Universitas \\ Udayana-RSUP Sanglah ${ }^{2}$ \\ Konsultas Radiologi Muskuloskeletal, Fakultas Kedokteran Universitas Udayana - RSUP \\ Sanglah ${ }^{3}$ \\ Jl. Diponegoro, Dauh Puri Klod, Kec. Denpasar Bar., Kota Denpasar, Bali 80113 \\ * e-mail: anast.tjan@gmail.com
}

\begin{abstract}
Abstrak
Tuberkulosis (TB) adalah salah satu ancaman utama dan beban di Indonesia. Meningitis TB (MTB) adalah bentuk infeksi TB yang paling parah. Evaluasi computed tomography (CT) pada diagnosis MTB dengan trias hidrosefalus, peningkatan meningeal basal dan infark dilaporkan sensitif. Polymerase chain reaction (PCR) likuor serebrospinalis (LCS) diketahui spesifik, namun hasil negatif telah dilaporkan karena adanya inhibitor PCR, lisis mikobakteria yang buruk, dan distribusi spesimen yang tidak merata. Computed tomography (CT) Scan merupakan modalitas yang penting dalam mendiagnosis MTB, yakni dengan mengenali trias CT pada pasien MTB terutama pola penyengatan sisterna basalis yang merupakan tanda khas penyengatan pada pasien MTB. Terdapat 9 penyengatan sisterna basalis (PSB) yang harus diketahui yakni kontras yang mengisi sisterna, garis ganda atau lipat tiga, penyengatan linear pada sistena arteri serebri media, tanda $Y$, penyengatan pada posterior resesus infundibulum, pola penyengatan dengan batas tidak tegas, penyengatan nodular, dan gambaran yang asimetris pada seluruh pola. Mengenali kriteria PSB sangat penting untuk memberikan diagnosis yang lebih tepat sehingga dapat mengurangi morbiditas dan mortalitas.
\end{abstract}

Kata Kunci: meningitis, tuberculosis, CT scan; neuroradiologi

\section{Basal Cistern Enhancement pattern in Tuberculosis Meningitis Patient on Computed Tomography Imaging: an illustrated review}

\begin{abstract}
Tuberculosis (TB) is one of the major worldwide threat and global burden in Indonesia. CNS tuberculosis is the most severe form of TB infection. CT evaluation on diagnosing tuberculosis meningitis (TBM) with triad of hydrocephalus, basal meningeal enhancement and infarction was reported to be sensitive. PCR cerebrospinal fluid (CSF) is known to be specific, however negative results have been reported due to presence of $P C R$ 's inhibitors, poor lysis of mycobacteria, and the uneven distribution in specimens. CT Scan plays the vital role in diagnosing TBM patient with the presence of TBM CT triad, especially basal cistern enhancement (BME) which is the specific enhancement pattern in MTB patient. There are 9 must know BME pattern, such as contrast filling the cistern, double and triple line, linear enhancement at MCA cistern, $Y$ sign, posterior infundibular recess enhancement, ill defined
\end{abstract}


Penyengatan Meningeal Sisterna Basalis Meningitis TB pada Computed Tomography... Anastasia Tjan, Made Widhi Asih, Elysanti Dwi Martadiani

border, join the dots sign, nodular enhancement, and asymmetry off all pattern. Familiarizing $B M E$ criteria is essential to provide confident diagnosis and reduce morbidity and mortality.

Keywords: Meningitis, Tuberculosis, CT Scan, Neuroradiology

\section{PENDAHULUAN}

Tuberkulosis (TB) merupakan suatu ancaman global dan memberikan beban sebesar 10,4 juta insiden kasus TB (Cl 8.8 juta-12 juta) atau setara dengan 120 kasus per 100.000 penduduk di Indonesia (Kementerian Kesehatan RI, 2018). Meningitis tuberkulosa (MTB) adalah bentuk infeksi bakteri mycobacterium paling parah dan mengancam nyawa. Adanya banyak rupa dari manifestasi bakteri ini membuat suatu tantangan dalam mendiagnosis. Adanya temuan klinis yang mengarah ke infeksi bakteri spesifik di meningeal didukung gambaran radiologi dan laboratorium akan dapat memberikan penanganan yang tepat dan lebih cepat, namun dengan berkembangnya jaman, bakteri ini seringkali memiliki banyak manifestasi dan kemampuan untuk kamuflase dengan penyakit lain bahkan hasil yang mengarah tanpa kelainan. Beberapa penelitian telah mengungkapkan bahwa temuan trias computed tomography (CT) scan pada pasien MTB yakni hidrosefalus, penyengatan meningeal sisterna basalis (PSB), dan infark, dilaporkan menjadi temuan yang sensitif (Andres et al, 2016). Analisis Polymerase chain reaction (PCR) liquor cerebrospinalis (LCS) juga diketahui spesifik terhadap MTB, namun beberapa laporan kasus dan literatur belakangan ini mengungkapkan hasil PCR negatif pada pasien MTB yang mana mungkin disebabkan oleh adanya inhibitor PCR pada kuman, dan kemampuan lisis bakteri yang kurang, kurang ratanya penyebaran specimen (DilAfroze et al, 2008), hasil negatif palsu tersebut dapat terjadi pada pasien dengan riwayat pengobatan TB sebelumnya (Bhigjee et al, 2007). Oleh karena itu pola penyengatan meningeal sisterna basalis (PSB) dalam trias CT perlu dikenal lebih baik agar dapat memberikan kepastian diagnosis untuk menentukan arah terapi.

\section{PEMBAHASAN}

\section{Meningitis Tuberkulosis}

Tuberkulosis merupakan penyakit infeksi yang disebabkan oleh bakteri mycobacterium yang dikenal memiliki morbiditas dan mortalitas tinggi terutama pada negara berkembang salah satunya adalah Indonesia. Tuberkulosis meningitis merupakan bentuk paling parah dari infeksi mycobacterium tuberkulosis yang menyebabkan disfungsi neurologi lanjut 
dan bahkan kematian. Temuan klinis yang seringkali tidak spesifik menjadi tantangan dalam mendiagnosis meningitis tuberculosis (MTB). (Andres et al, 2016) Pada anak-anak gejala awal tidak spesifik yakni termasuk batuk, demam, muntah (tanpa diare), malaise, dan menurunnya berat badan. Pada pemeriksaan fisik biasanya didapatkan kondisi yang apatis atau iritabilitas yang dapat berkembang menjadi meningismus seperti, menurunnya tingkat kesadaran, tanda-tanda peningkatan tekanan intrakranial (fontanelle anterior menonjol dan paralisis saraf abducens) serta tanda neurologis fokal (paling sering hemiplegia). Pada orang dewasa biasanya terdapat gejala prodromal non-spesifik seperti malaise, penurunan berat badan, demam ringan, dan sakit kepala yang dapat bertahap selama 1-2 minggu lamanya. Gejala tersebut dapat memburuk hingga penurunan kesadaran dan kematian apabila terapi tidak diberikan. Pada pemeriksaan fisik biasanya terdapat kekakuan leher, kelumpuhan saraf cranial, yakni saraf cranial VI, III, VII, monoplegia, hemiplegia, atau paraplegia juga dapat ditemukan sekitar 20\% kasus. (Thwaites et al, 2013)

\section{Pemeriksaan Likuor Cerebrospinalis Meningitis Tuberkulosis}

Pemeriksaan likuor cerebrospinalis yang menyokong suatu MTB adalah level glukosa yang rendah $(<40 \mathrm{mg} / \mathrm{dl})$ dengan dominasi mononuclear, dominasi polymorphonuclear dapat tampak pada kasus awal, peningkatan jumlah sel (1010.000), serta total protein $>50 \mathrm{mg} / \mathrm{dl}$. (Solari et al, 2013)

Analisis PCR untuk deteksi DNA mycobacterium tuberculosis merupakan temuan yang spesifik terhadap diagnosis MTB dan lebih sensitif terhadap pemeriksaan bakteriologi konvensional. Namun beberapa studi melaporkan adanya pasien MTB dengan hasil PCR negatif sebaliknya hasil kultur positif disertai adanya perubahan signifikan secara klinis dan laboratorium pada terapi obat anti TB (OAT). Sensitifitas PCR yang rendah pada studi tersebut dapat dijelaskan oleh karena adaya inhibitor PCR yang terdapat dalam reaksi, lemahnya lisis mycobacterium, dan distribusi spesimen yang tidak merata. (Chawla et al, 2017) Selain itu pasien yang sudah menderita TB sebelumnya dengan terapi OAT juga dapat memberikan hasil negatif palsu PCR. (Bhigjee et al, 2007) Pada dua studi yang dilakukan sebelumnya didapatkan sensitivitas PCR TB dalam mendiagnosis MTB yakni 32 dan 85\%. (DilAfroze et al, 2008) 
Penyengatan Meningeal Sisterna Basalis Meningitis TB pada Computed Tomography... Anastasia Tjan, Made Widhi Asih, Elysanti Dwi Martadiani

\section{Pencitraan Diagnosis Meningitis}

Tuberkulosis

CT scan dengan kontras merupakan pencitraan diagnostik yang mudah, cepat, dan minimal invasif yang dapat digunakan untuk mengevaluasi MTB. Peranan CT Scan sangat penting dalam mendeteksi tandatanda seperti trias $\mathrm{CT}$, penyengatan meningeal sisterna basalis (PSB), serta dapat mengenal fitur komplikasi dari MTB. (Andres et al, 2016) Beberapa studi terkahir telah mengemukakan bahwa tanda radiologis MTB melalui CT scan yakni trias CT yang meliputi hidrosefalus, infark, dan PSB. Tuberkuloma dan edema serebri juga dapat ditemukan pada pemeriksaan CT scan pasien MTB. Berbagai penelitian sebelumnya telah mengemukakan bahwa temuan trias CT pada pasien MTB merupakan temuan yang sensitif dan spefisik terhadap MTB. (Andronikau dan Wieselthaler, 2004, Botha et al, 2012)

Hidrosefalus ditemukan pada CT Scan dengan adanya dilatasi simetris atau asimetris sistem ventrikel. Hidrosefalus merupakan temuan yang cukup sering dicatat pada pasien MTB. Tipe hidrosefalus tipe obstruktif pada pasien MTB disebabkan oleh adanya eksudat dan inflamasi pada leptomeninges yang menyumbat aliran keluar ventrikel 4 atau obstruksi pada aqueductus Sylvii. (Raut et al, 2013) Hidrosefalus komunikans biasanya terjadi akibat produksi berlebih cairan LKS atau menurunnya penyerapan LKS pada ruang subaraknoidalis.

Eksudat inflamasi MTB sebagian besar mengisi sisterna subaraknoid basalis di sekitar sirkulus Willisi. Pembuluh darah yang paling sering terkena merupakan pembuluh darah cabang seperti arteri lentikulostriata yang merupakan pembuluh darah cabang dari arteri serebri media. Eksudat tersebut akan mengakibatkan iskemia dan infark pada daerah pembuluh darah yang terkena, seperti pada basal ganglia, kapsula interna, thalamus, dan lainnya. Terjadinya iskemia dan infark pada pasien MTB diawali dengan arteritis, thrombosis, dan obstruksi. Gambaran iskemia dan infark pada CT Scan menunjukkan suatu lesi dengan densitas rendah dengan pengaburan batas korteks dan lobus. (Andres et al, 2016)

Pemeriksaan CT dengan kontras merupakan pilihan modalitas pada pasien yang dicurigai terkena MTB, namun kadang pada pemeriksaan CT tanpa kontras eksudat inflamasi TB dapat tampak sebagai lesi isodense atau hiperdense terhadap sistena basalis.

Sensitivitas dan spesifisitas temuan PSB pada penelitian yang dilakukan sebelumnya hingga $73 \%$ (sensitivitas) dan 88\% (spesifisitas). (Andres et al, 2016) 
Terdapat 9 PSB dan dikemukakan oleh literatur sebelumnya bahwa terdapat 4 kriteria yang memberikan baik spesifisitas dan nilai prediktor positif sebesar $100 \%$, sedangkan kriteria yang lain memiliki spesifitas lebih dari $90 \%$ kurang dari $100 \%$ dengan nilai predictor positif di antara $90-97 \%$. Ke-empat criteria tersebut yakni garis berganda, penyengatan pada aspek posterior resesus infundibular, penyengatan nodular, dan tanda join the dot. (Przybojewski et al, 2006) Kriteria yang paling sensitif adalah pola penyengatan berbatas kabur, dan kontras yang mengisi sisterna dengan sensitifitas $82 \%$ pada kedua pola PSB tersebut. Dengan ditemukannya pola penyengatan PSB lebih dari 2 kriteria dapat meningkatkan sensitivitas diagnosis MTB hingga 91\% pada CT Scan dengan kontras. (Przybojewski, Andronikou dan Wilmshurst, 2006)

Beberapa proses granulomatosa selain TB juga dapat memberikan PSB yang serupa, seperti penyakit sarkoidosis, granulomatosis Wegener, agen infeksius bakteri non-TB seperti, jamur, parasit juga dapat menyebabkan PSB yang serupa. Metastase pada ruang meninges juga dapat memberikan pola yang mirip sehingga manifestasi klinis dan pemeriksaan lainnya harus dilakukan untuk menunjang gambaran diagnosis MTB.

\section{Pola Penyengatan Meningeal Sisterna Basalis pada CT Scan}

Terdapat 9 kriteria penyengatan sisterna basalis pada pasien MTB pada CT Scan yakni kontras yang mengisi sisterna, garis berganda atau lebih, asimetrisitas, tanda $Y$, penyengatan linear, penyengatan pada aspek posterior resesus infundibular, penyengatan nodular, penyengatan batas tidak tegas, dan join the dot sign.

\section{Kontras Mengisi Sisterna Basalis}

Kontras yang mengisi sisterna basalis merupakan suatu gambaran hiperdense, berdensitas tinggi oleh karena adanya materi kontras yang diinjeksikan secara intravena dan tampak cairan tersebut mengisi mengelilingi pembuluh darah sekitar arter serebri media (Gambar 1). (Andres et al, 2016) (Sanei et al, 2015) Penyengatan ini merepresentasikan penyengatan vaskular normal yang terobliterasi oleh kontras. (Przybojewski et $a l, 2006)$

\section{Penyengatan Garis Berganda atau Lebih}

Pola ini merupakan penyengatan berbentuk garis berganda atau lebih yang tampak pada arteri serebri media dan diakibatkan oleh penyengatan meningeal yang melapisis lobus frontalis dan temporalis yang saling berdekatan (Gambar 2-3). 
Penyengatan Meningeal Sisterna Basalis Meningitis TB pada Computed Tomography... Anastasia Tjan, Made Widhi Asih, Elysanti Dwi Martadiani

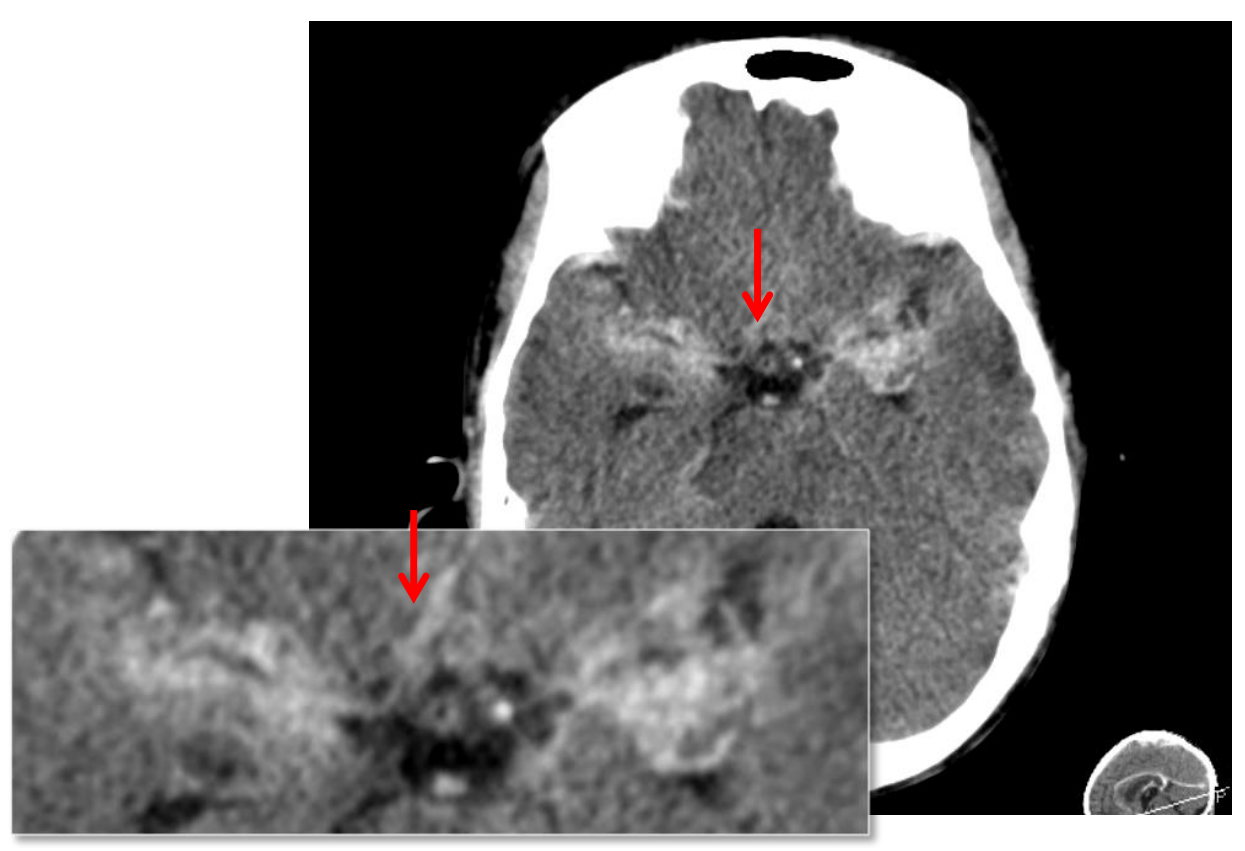

Gambar 1. Kontras mengisi sisterna. Tampak lesi hiperdense mengisi sisterna basalis yang merupakan ekstravasasi dari media kontras.

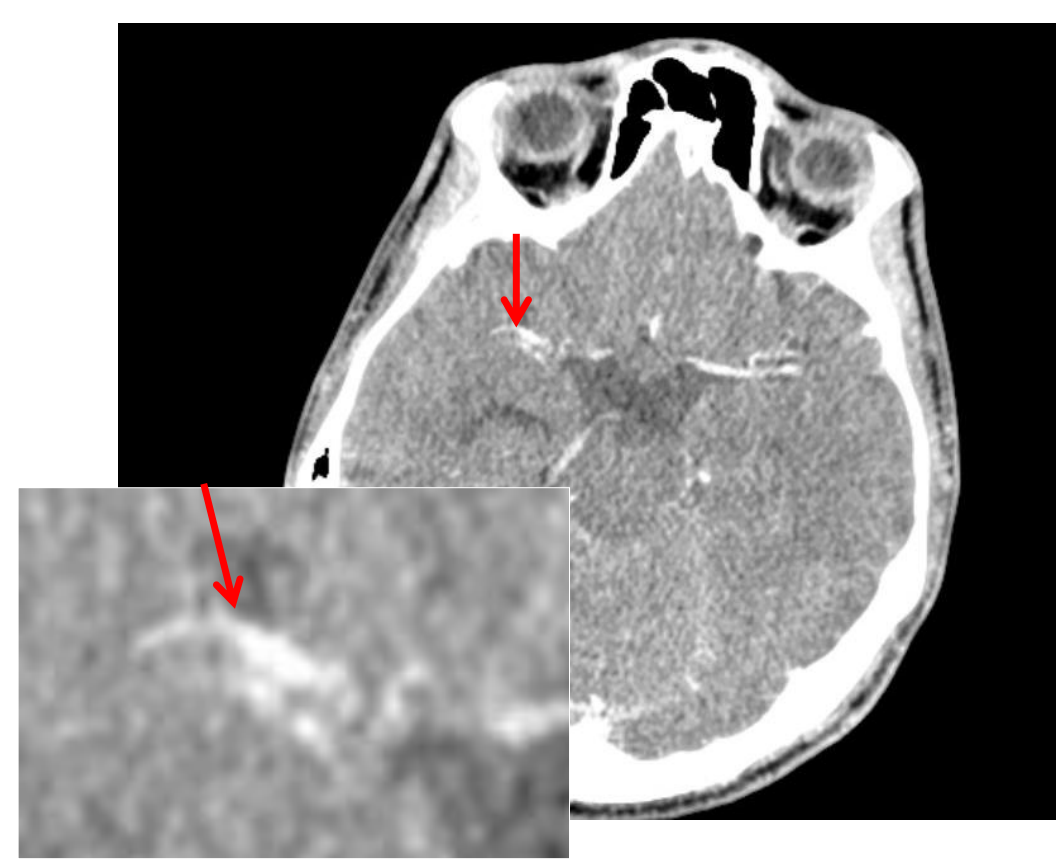

Gambar 2. Pola PSB yang berupa garis ganda yang teridentifikasi pada area arteri serebri media, 


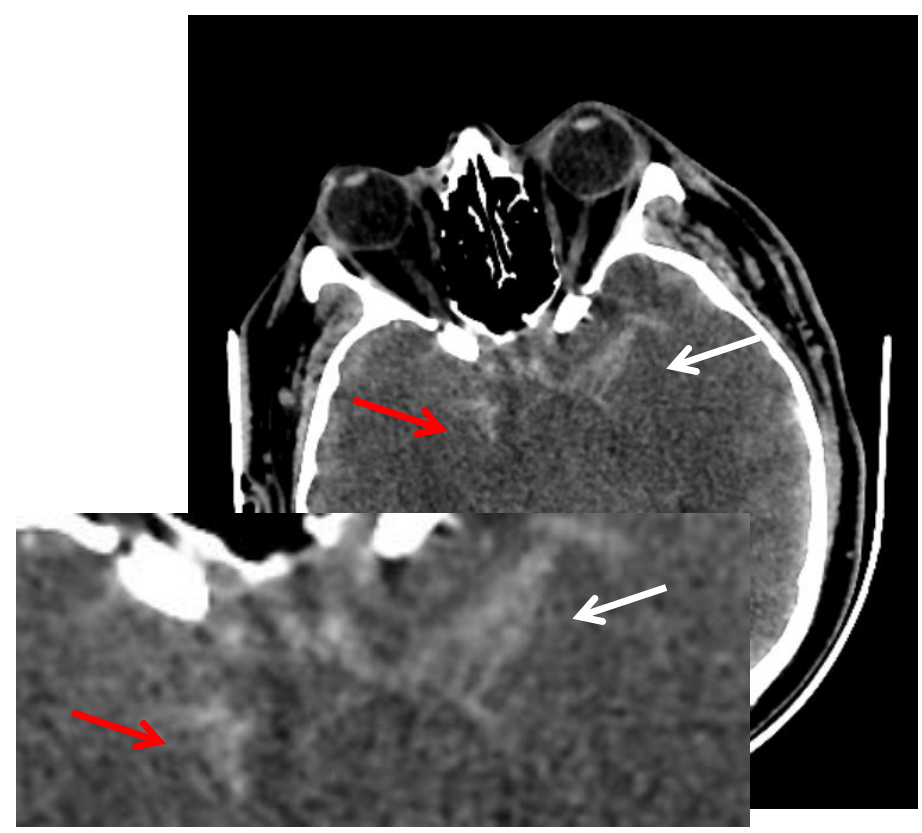

Gambar 3. Contoh lain dari pola PSB dengan garis ganda sisi kanan (panah merah), dan garis lipat 3 pada sisi kiri (panah putih).

\section{Asimetrisitas}

Asimetris merupakan temuan gambaran PSB apa saja yang tampak pada CT Scan secara bilateral namun asimteris (Gambar 4).

\section{Tanda Y}

Pola PSB berupa tanda Y didapatkan dengan adanya penyengatan pada pertemuan antara sisterna supraselar dan arteri serebri media (Gambar 5). (Andres et al, 2016).

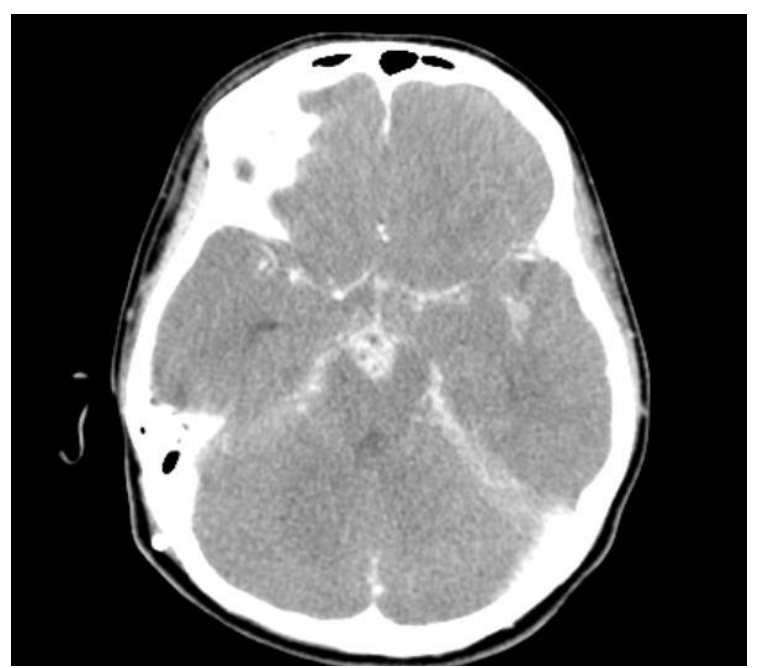

Gambar 4. Pola PSB asimetrisitas. 


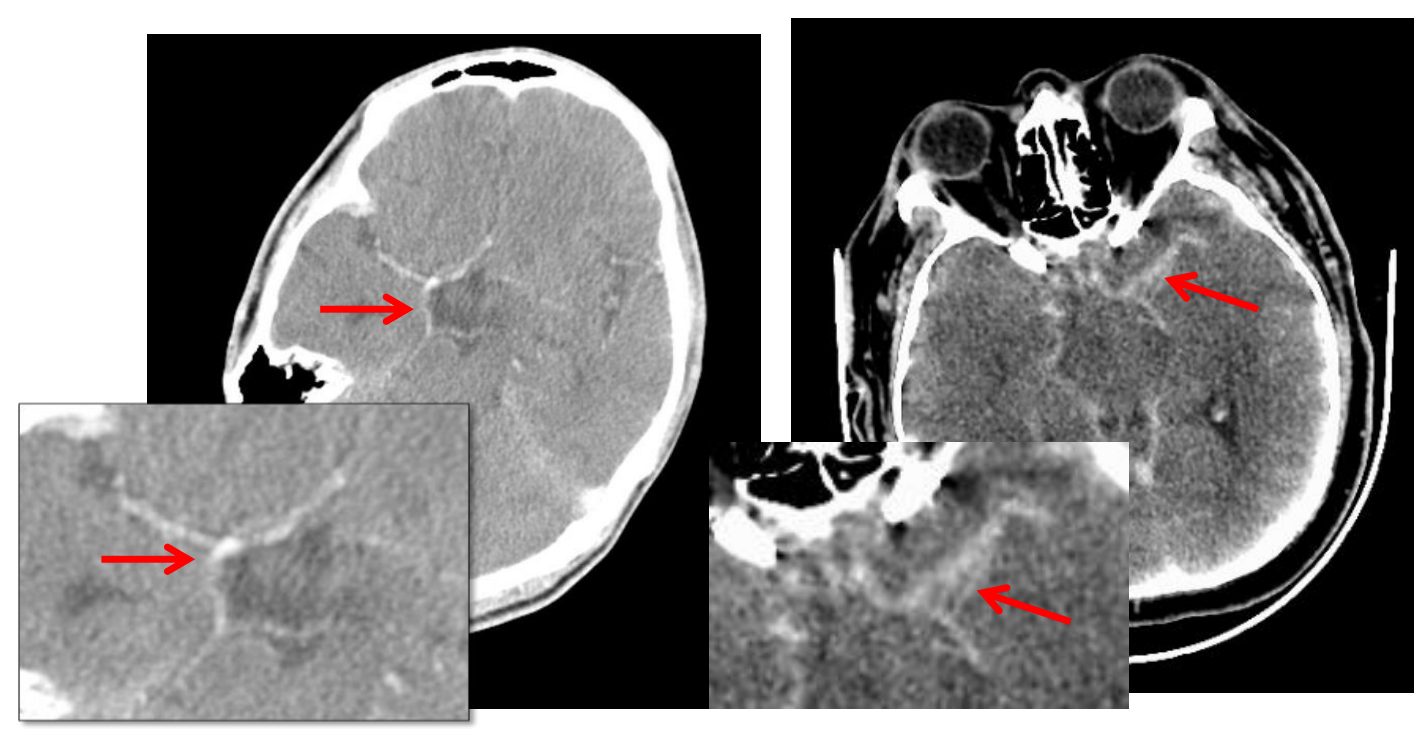

A

B

Gambar 5. A-B)Tanda Y

\section{Penyengatan Linear}

Dapat disebut suatu penyengatan linear apabila tampak penyengatan pada area sistena arteri serebri media berbentuk linear yang tampak lebih dari 2 potongan aksial CT scan kepala (Gambar 6).

\section{Penyengatan pada posterior resesus infundibular}

Gambaran hiperdensitas pada aspek posterior resesus infundibular ventrikel 3 pada sisterna supraselar (Gambar 7).

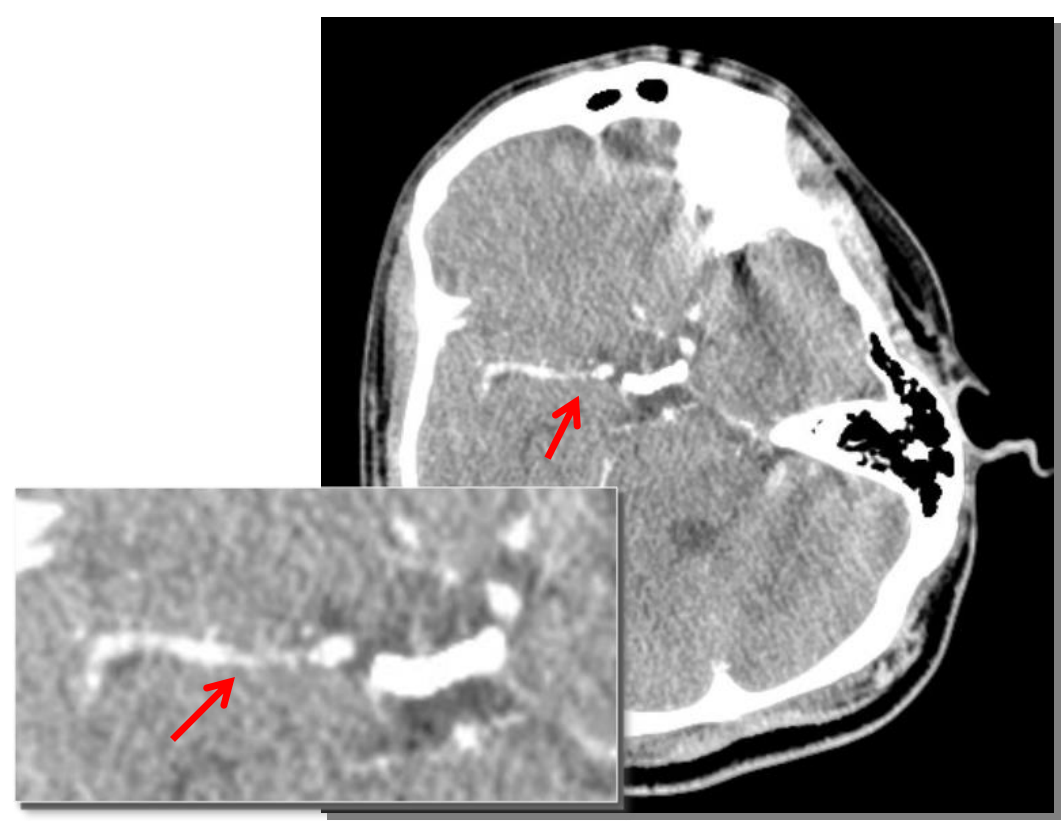

Gambar 6. Penyengatan linear pada pola PSB 


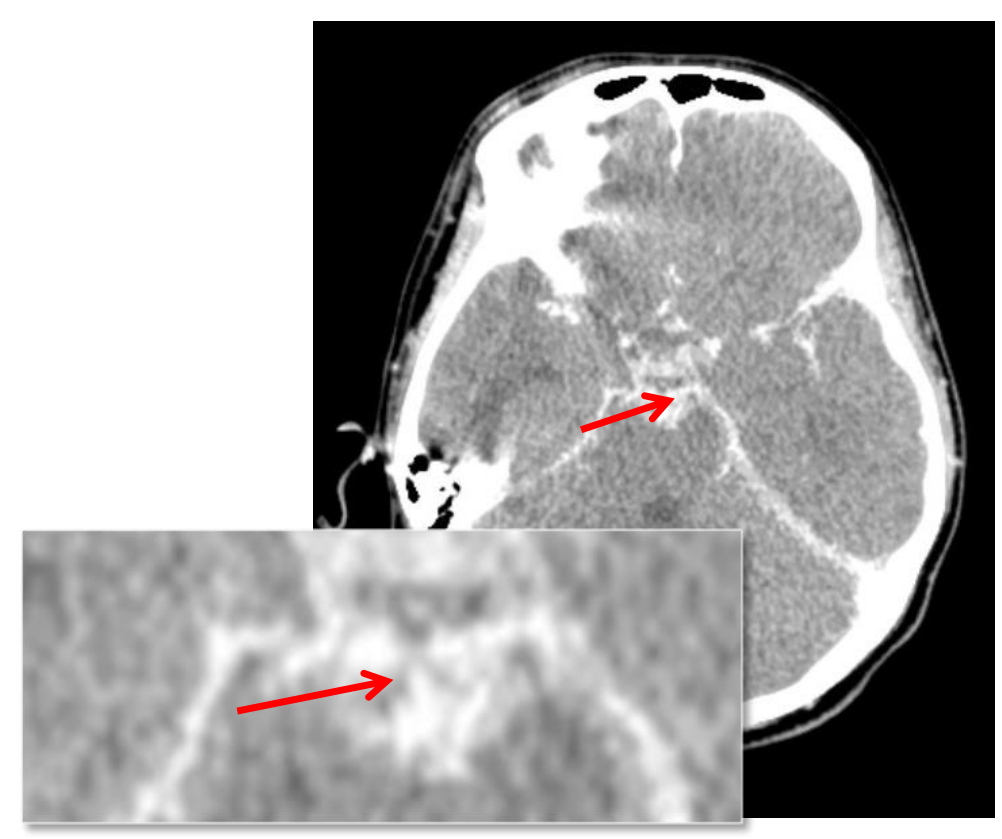

Gambar 7. Penyengatan pada aspek posterior resesus infundibular.

\section{Penyengatan Nodular}

Penyengatan berbentuk nodular selalu merupakan suatu tanda patologis. Meninges dan pembuluh darah yang normal biasanya selalu berbentuk regular, licin, mulus, dan berbatas tegas (Gambar 8). (Przybojewski et al, 2006)

\section{Penyengatan Batas Tidak Tegas \\ Penyengatan pada sistena basalis dengan batas yang kabur, dan tidak tegas dapat dilihat pada gambar 9. (Andres et al, 2016).}

\section{Join The Dot Sign}

Tanda join the dot merupakan pola penyengatan pada fisura Sylvii, dimana pada kondisi normal kontras pada fisura Sylvii akan memberikan gambaran titik-titik yang tidak tersambung satu dengan yang lainnya pada berbagai potongan aksial CT scan kepala. Pada pasien MTB gambaran titik-titik tersebut seperti menyatu dan membentuk sebuah alur yang berjalan terus pada tiap potongan aksial CT Scan. (Gambar 10) (Andres et al, 2016). 
Penyengatan Meningeal Sisterna Basalis Meningitis TB pada Computed Tomography... Anastasia Tjan, Made Widhi Asih, Elysanti Dwi Martadiani

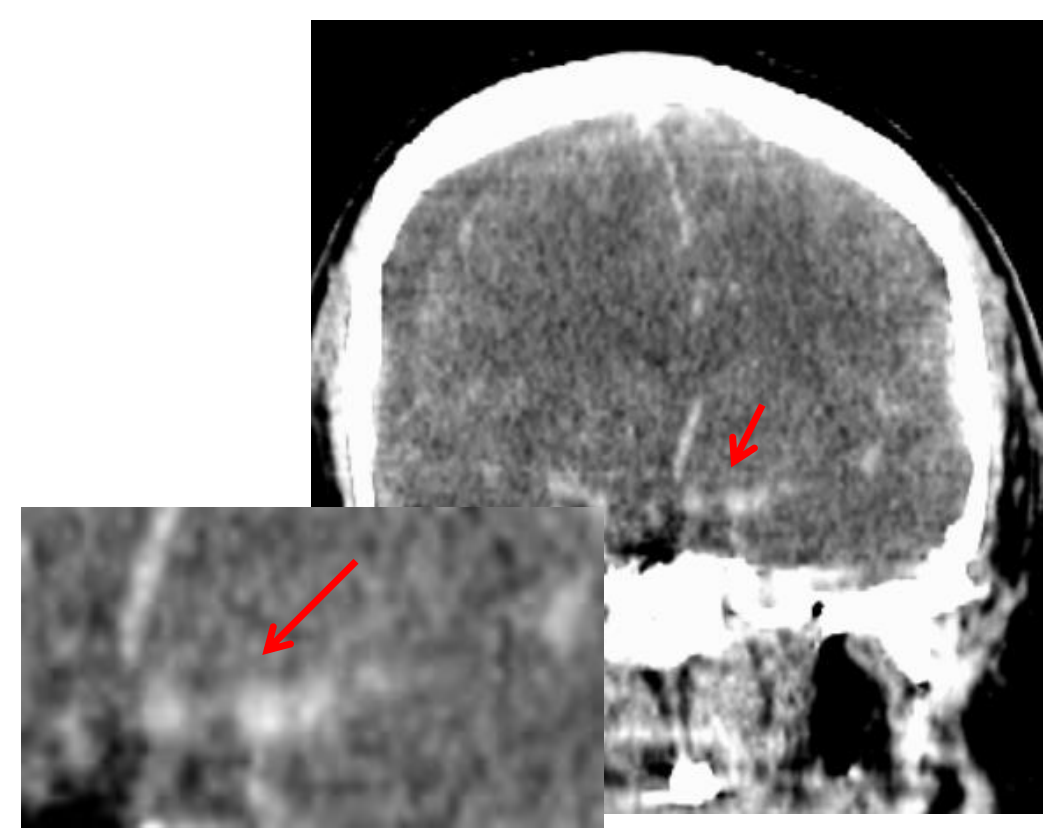

Gambar 8. Penyengatan nodular.

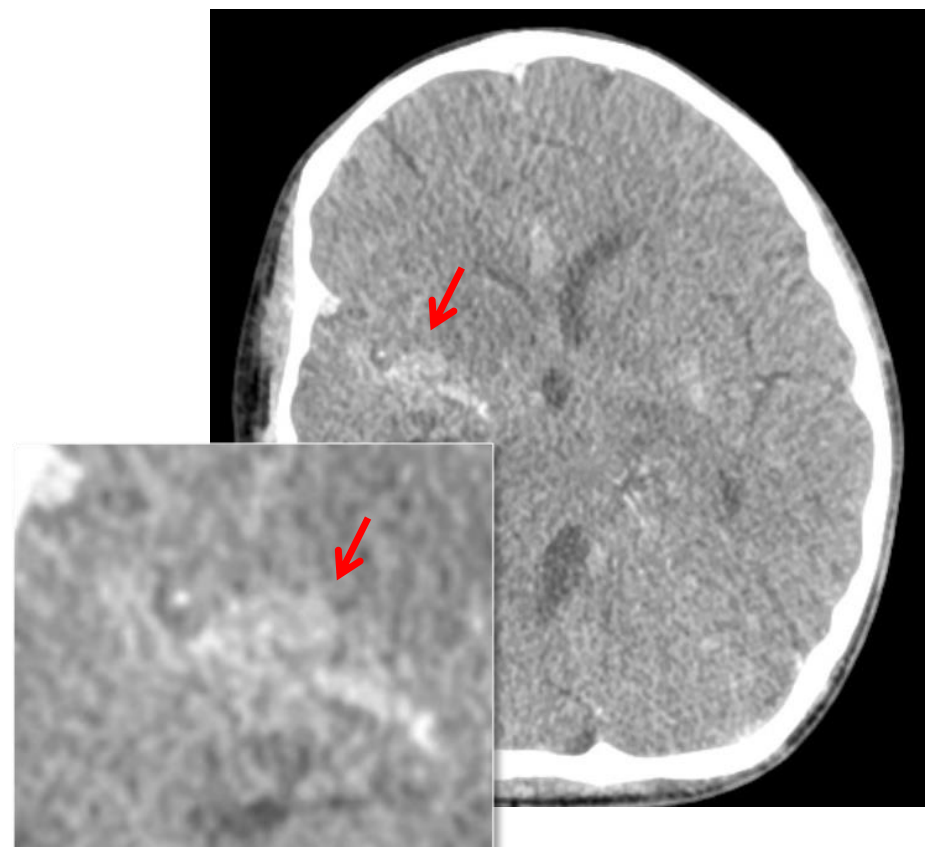

Gambar 9. Penyengatan dengan batas tidak tegas. 


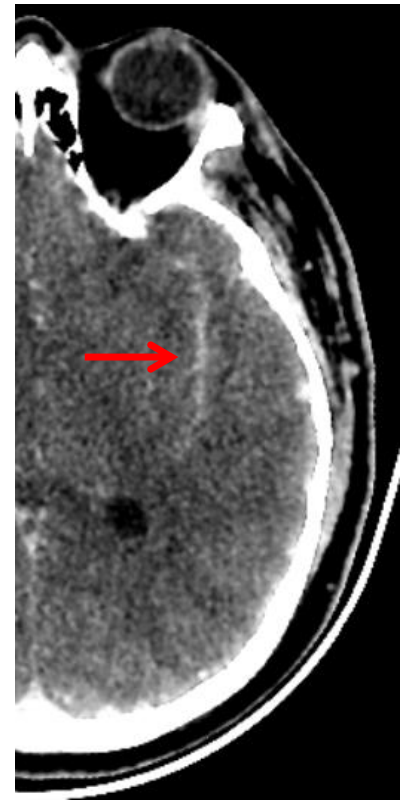

A

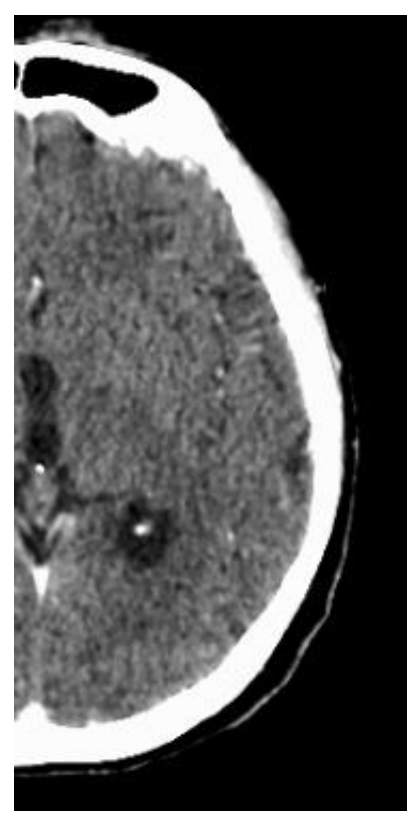

B

Gambar 10. A) Tampak penyengatan pada fisura Sylvii dengan tanda join the dot (panah). B) gambaran normal fisura sylvii pada CT scan kepala dengan kontras.

\section{KESIMPULAN}

Terdapat 9 pola PSB pada CT Scan kepala dengan kontras yang dapat membantu dalam mendiagnosis MTB. Selain itu gambaran selain PSB pada trias CT yakni hidrosefalus dan infark juga dapat digunakan sebagai pertimbangan adanya infeksi spesifik MTB. Dari 9 kriteria apabila terdapat 2 kriteria atau lebih terutama dari 4 kriteria PSB yang memberikan spesifitas $100 \%$ (garis berganda, penyengatan pada aspek posterior resesus infundibular, penyengatan nodular, dan tanda join the dot) dapat meningkatkan lebih dari $91 \%$ keyakinan dalam mendiagnosis MTB. (Przybojewski et al, 2006)

\section{DAFTAR PUSTAKA}

Andres MM, Uy JAU, and Reyes-Paguia MP, 2016. Tuberculous Meningitis Basal Cistern Enhancement Pattern on CT imaging. TB Corner, 2(5):1-9

Andronikou S dan Wieselthaler N, 2004. Modern imaging of tuberculosis in children: thoracic, central nervous system and abdominal tuberculosis. Pediatric Radiology. 34(11): 861-875

Bhigjee A, Padayachee R, Paruk H., Hallwirth-Pillay $K$, Marais $S$ dan Connoly C, 2007. Diagnosis of tuberculous meningitis: clinical and laboratory parameters. 
Penyengatan Meningeal Sisterna Basalis Meningitis TB pada Computed Tomography... Anastasia Tjan, Made Widhi Asih, Elysanti Dwi Martadiani

International Journal of Infectious

Diseases. 11(4):348-354

Botha H, Ackerman C, Candy S, Carr J, Griffith-Richards S dan Bateman K, 2012. Reliability and Diagnostic Performance of $\mathrm{CT}$ Imaging Criteria in the Diagnosis of Tuberculous Meningitis. PLOS ONE. 7(6): e38982

Chawla K, Berwal A., Vishwanath S dan Shenoy V, 2017. Role of multiplex polymerase chain reaction in diagnosing tubercular meningitis. Journal of Laboratory Physicians. 9(2): 145.

Dil-Afroze, Mir A, Kirmani A, Shakeel-ulRehman, Eachkoti $\mathrm{R}$ dan Siddiqi $M, 2008$. Improved diagnosis of central nervous system tuberculosis by MPB64-Target PCR. Brazilian Journal of Microbiology. 39(2): 209-213.

Kementerian Kesehatan Republik Indonesia, 2018. Tuberkulosis. http://www.depkes.go.id/article /view/13010100001/profil-visidan-misi.html

Przybojewski S, Andronikou S dan Wilmshurst J, 2006. Objective CT criteria to determine the presence of abnormal basal enhancement in children with suspected tuberculous meningitis. Pediatric Radiology. 36(7): 687-696.

Raut T, Garg R, Jain A, Verma R, Singh M, Malhotra $\mathrm{H}$, Kohli $\mathrm{N}$ dan Parihar A, 2013. Hydrocephalus in tuberculous meningitis: Incidence, its predictive factors and impact on the prognosis. Journal of Infection. 66(4): 330337.

Sanei Taheri M, Karimi M, Haghighatkhah H, Pourghorban R, Samadian M dan Delavar Kasmaei H, 2015. Central Nervous System Tuberculosis: An Imaging-Focused Review of a Reemerging Disease. Radiology Research and Practice.1-8

Solari L, Soto A, Agapito J, Acurio V, Vargas D, Battaglioli T, Accinelli R, Gotuzzo E dan van der Stuyft P, 2013. The validity of cerebrospinal fluid parameters for the diagnosis of tuberculous meningitis. International Journal of Infectious Diseases. 17(12): e1111-e1115

Thwaites G, van Toor, R dan Schoeman J, 2013. Tuberculous meningitis: more questions, still too few answers. The Lancet Neurology. 12(10): 999-1010. 